\title{
A proposal for a modified Human Development Index
}

\author{
María Andreina Salas-Bourgoin
}

ABSTRACT

The Human Development Index (HDI) is an indicator designed to track the development of countries in respect of three dimensions of development: health, education and income. Since it was first published in 1990, great efforts have been made to improve HDI, which, as has been stressed on numerous occasions, cannot be seen as a definitive measure of development. This paper includes a reflection on what constitutes human development, the pillars underpinning it and two new dimensions that should be incorporated into HDI (employment and political freedoms) for it to better express progress in development. This document will also present, in addition to the modified HDI, detailed instructions for its calculation and an annex including modified HDI scores for 117 countries.

KEYWORDS

JEL CLASSIFICATION

AUTHOR
Human development, measurement, UNDP, economic indicators, social indicators, statistical methodology, statistical data

I31, I32, I39

María Andreina Salas-Bourgoin is a full-time assistant professor at the Institute of Geography and Natural Resource Conservation of the University of Los Andes, Merida, Bolivarian Republic of Venezuela. bourgoin@ula.ve 


\section{I}

\section{Introduction}

The Human Development Index (HDI) is an aggregated indicator, designed by the United Nations Development Programme (UNDP) to track progress in the development of countries and provide useful information for policymakers. Since it was first published in the 1990 Human Development Report, it has become widely accepted as a global yardstick for the development performance of nations and a starting point for drawing up rankings.

Because HDI plays such an important role in, for example, studies on quality of life, equity and social justice, UNDP has devoted considerable effort to improving it. These attempts have been directed both at accurately gauging living standards and at providing evidence of progress, stagnation and regression in the formation of human capabilities, enlarging people's choices and access to other opportunities that allow individuals to realize long-held aspirations.

An important milestone was reached in 2010 when that year's Human Development Report included an HDI calculated using new indicators so as to take account of education and income, together with a new index, the Inequality-adjusted HDI (IHDI), which measured inequalities in each of the dimensions making up the original index.

The HDI has thus far been calculated on three dimensions: health, education and income. The aim is to reflect, using specific criteria, the multidimensional nature of development by introducing elements that, for various reasons, are considered to be of the utmost importance in the creation of human capabilities, opportunities and choices: mean years of schooling, expected years of schooling, life expectancy at birth and gross national income per capita. However, as many far-reaching studies have shown, development goes beyond these factors to encompass others such as environmental sustainability, employment or freedom that are just as relevant in gauging progress in it.
Therefore, with a view to fuelling further debate on these issues, a proposal has been made for a modified HDI, on the basis of a review of the literature and statistics, which incorporates two fundamental dimensions for development:

(i) Employment, as it provides more than merely the financial means to satisfy people's material needs and lift them out of poverty and is also a source of human dignity.

(ii) Democracy, as it is the form of government which, by virtue of the development and quality of life it brings, is most widely respected and which most effectively safeguards individual and collective freedoms.

This proposal uses the same criteria for selecting indicators and the same method of calculation as UNDP. Two indicators are proposed for the measurement of employment: the employment-to-population ratio and the share of non-vulnerable employment in total employment. The Democracy Index (DI) is proposed as a way of gauging freedom.

With a view to illustrating how the modified HDI works and what a useful tool it can be in analysing the development strengths and weaknesses within and between countries, the index has been calculated for 2012 using data from UNDP, the International Labour Organization (ILO) and the Economist Intelligence Unit (EIU) on a set of countries in different continents.

After the introduction, this article includes the following sections: section II, which provides a brief overview of human development as a model of development, including a precise explanation of what it should mean for human beings; section III discusses HDI as the foremost indicator of progress in human development; section IV examines the basic premises of HDI; section V concerns employment and freedoms; section VI presents the modified human development index and section VII delivers the conclusions. 


\section{II}

\section{Human development as a development model}

From the 1980s onwards, with Max-Neef's writings on human-scale development and Sen's notion of development as a process of enhancing people's freedoms to enable them to realize their aspirations, human beings have been considered the focal point and ultimate beneficiary of development. Economic growth was no longer seen as the be-all and end-all, and ensuring quality of life and creating conditions conducive to the achievement of individual and collective goals became the overriding aim.

In the late 1980s this line of thinking gave rise to the concept of human development, defined as the process of expanding, by creating capabilities, the range of opportunities and choices open to people for them to have a quality of life able to match their hopes and dreams. Creating capabilities is understood in this instance to mean enhancing people's skills for the purposes of autonomous development, doing things, existing or acting, as Sen pointed out in 1988, in his speech at the Wider Conference on Quality of Life ${ }^{1}$ (Vethencourt, 2008).

As Recalde (1999) has noted, individuals must have the right to equal opportunities with which to make the most of their capabilities. The way in which people actually take the opportunities offered by society and use the resources they obtain is their choice, but within a society the freedom to choose, both in the present and in the future, is paramount. "The real objective of development is to improve people's choices" (UNDP, 1992).

Sen (2000) saw development as the strengthening of five types of freedom: political freedoms, economic facilities, social opportunities, transparency guarantees and protective security. Political freedoms are linked to human rights, the possibility of electing one's leaders in a climate of press freedom without censorship and the right to free association and to criticize and investigate authorities.

Economic facilities, meanwhile, are opportunities to use economic resources and to consume, produce, trade and to engage in transactions. Social opportunities refer to health care, education and other services which are essential for the population. Transparency guarantees ensure that business relationships are underpinned

1 Conference on the quality of life of the United Nations University World Institute for Development Economics Research. by trust between parties concerning the nature of what is offered and, lastly, protective security entails a social safety net to reduce people's vulnerability (Hernández, 2008).

According to the Human Development Report 1992, development should be by, of and for the people. It should therefore enable individuals to take an active part in all spheres of society and in the planning and implementation of activities aimed at improving the quality of their lives and meeting their needs, within a scenario of greater opportunities.

But what does the widening of opportunities and choices as part of human development mean?

It is the creation of a scenario which enables individuals and groups to achieve a better quality of life by making use of the instruments, tools and goods needed for them to attain the goals they have set and to contribute to achieving the objectives of the society of which they are members.

These choices represent the whole range of possibilities open to individuals to increase their quality of life and realize their aspirations, i.e. as the word itself makes plain, the ability to choose from a wider range of things that an individual can do or be, which entails liberty and free choice (UNDP, 2000).

It therefore follows that: (i) the various choices should be qualitatively and quantitatively different; (ii) there should be no obligation to make any specific choice and individuals should, therefore, have the awareness or clarity to make the choice, from the range of options open, that is most closely aligned with their interests and value system, and (iii) people must be free to choose the option that best suits them.

In respect of opportunities, human development equates to bringing about equitable conditions that enable individuals to take advantage of the choices they have made. This would require an "enabling" environment, in other words, a context in which individuals and society at large can, by and large, realize their aspirations because they have been provided with the basic means for doing so.

People in societies with a high level of human development can therefore be expected to be able to make choices and have access to the means to ensure that they become reality, to choose, according to their aspirations, 
the quality of life they desire and to obtain the goods, services and material and spiritual living conditions to enable them to achieve it without - as the Human Development Report 1992 rightly stresses - depriving others or other generations of them. Human development should thus be sustainable at both the intragenerational and the intergenerational level.

The logic of human development dictates that the choices and opportunities it offers are "endless". The following conditions are, however, essential: (i) a long life, (ii) the acquisition of knowledge and (iii) access to the necessary resources to satisfy basic needs and "achieve a decent standard of living". However, as a result of "distortions in the development process", 2 the positive combination of these three factors does not always lead to development; factors such as full employment, freedom and environmental quality are also fundamental in facilitating individual and collective development.

It could be, for example, that, despite a relatively high average number of years of schooling and, most importantly, of expected years of schooling, people have insufficient choices to benefit from the capacities

2 Changes for the worse that will inevitably take place during development. that have been created because the supply of jobs is restricted or insufficiently diversified or employment is poorly remunerated. Such a situation would not be an example of a high level of human development, because even though there is a skilled labour force, the "limited" context has given rise to unemployment, low wages, or underemployment.

There may also be societies that make adequate provision for health care and education and enjoy a high per capita gross national income but curtail political pluralism, legal equality, due process and free speech. In such a case, the level of human development appears high but is actually not, since it runs counter to the UNDP idea of development: "Freedom is more than an idealistic goal -it is a vital component of human development" (UNDP, 1992, p. 72).

As these cases illustrate, a level of human development that appears high may hide a non-sustainable material lifestyle which endangers the sustainability of the quality of life achieved and its continuity to future generations.

Distortions of this type suggest that human development encompasses more than education, health and income. It is a society's ability to provide the right conditions for individuals to achieve a better quality of life, which include employment and freedom. A breakdown of this approach is shown in figure 1 .

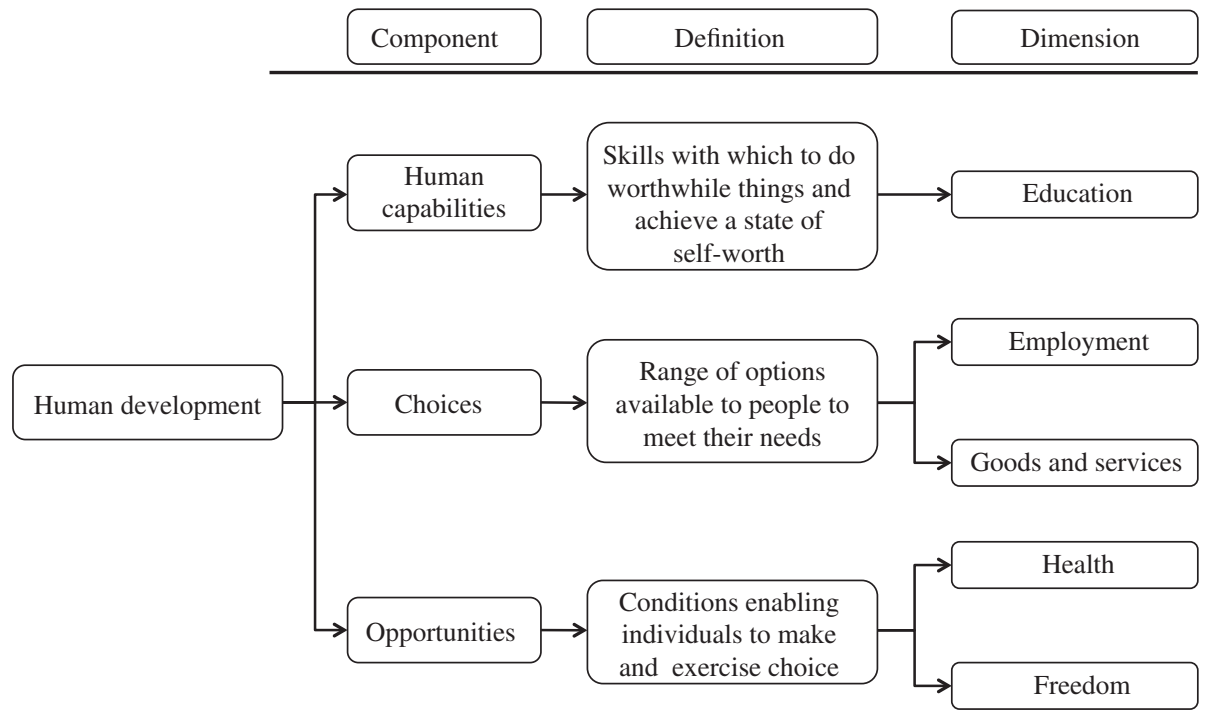

Source: prepared by author. 


\section{III}

\section{Human Development Index}

The Human Development Index (HDI) has been published each year since the first Human Development Report in 1990, and has become a widely accepted yardstick of progress in development that also breaks down this progress into the performance of societies in three key areas of life: health, education and income. Health is assessed by life expectancy at birth, education by the mean years of schooling for adults and the expected years of schooling for children and income by gross national income (GNI) per capita.

As an indicator, it is "... a mathematical relationship that expresses how various inputs — such as nutrition or primary schooling — produce a certain level of human development" (UNDP, 1992, p. 52). The formula for its calculation is as follows:

$$
\text { HDI }=\sqrt[3]{\text { Health.sub } \times \text { Education.sub } \times \text { Income.sub }}
$$

where:

Health subindex is estimated on the basis of life expectancy at birth;

Education subindex is estimated on the basis of the geometric mean of mean years of education of adults and the expected years of education for children;

Income subindex is estimated on the basis of gross national income (GNI) per capita.

The formula is a quantitative approximation of the creation of: (i) human capabilities as measured by education, (ii) choices, as measured by the possibility of acquiring goods and services and (iii) opportunities, as measured by health.

From 1990 to 2009, HDI was calculated on rates of literacy and gross school enrolment, as well as life expectancy at birth and gross domestic product (GDP) per capita. Expert opinion held that even if it were possible to use a greater number and wider variety of indicators to obtain a broad view of development, this could produce a perplexing picture and perhaps undermine the utility of the HDI for policymaking (UNDP, 1990). The decision was therefore taken not to load the HDI at the outset with burdens but rather to improve it incrementally (UNDP, 1992).

From the outset, the most widely debated and controversial element of the HDI was freedom. The Human Development Report 1992 noted in this regard that "...no measure of freedom can do it full justice... and while many of the quantitative measures that are developed may be no more than rough approximations, they can be an important stimulus to thought and debate" (UNDP, 1992, p. 72).

The report also introduced the political freedom index (PFI), an indicator focused on: (i) personal security, (ii) the rule of law, (iii) freedom of expression, (iv) political participation and (v) equality of opportunity. Its most apposite conclusions were, firstly, that: "Political freedom and human development do seem to move in tandem. Countries with a high HDI have an average PFI of $84 \%$, while countries with a low HDI have an average PFI of 48\%" (UNDP, 1992, p. 83); and, secondly, that the PFI was highly subjective and based on yes-no questions, which meant that further fine-tuning of the quantification and weighting system was needed.

In an effort to measure the level of development in countries in a more comprehensive manner, each year the Human Development Reports incorporated more and more indicators on key variables, which led to the compilation of statistical yearbooks on sensitive issues such as health, education, well-being, the environment, the economy and gender, but, strangely, no indicators on freedom were included.

UNDP capitalized on this progress in 2010 by making amendments to the HDI which entailed both replacing certain indicators and changing the method for its calculation. While the same structure, based around three dimensions, was maintained, the following replacements were made: (i) GDP per capita was abandoned in favour of GNI per capita, and (ii) the rates of literacy and gross school enrolment were substituted by mean years of schooling for adults and the expected years of schooling for children. Similarly the method of aggregation was changed from an arithmetic mean to a geometric meanand the upper and lower bounds used to normalize the index were redefined (Klugman, Rodríguez and Choi, 2011).

The Human Development Reports posit that nations make progress periodically. This is reflected in changes to their HDIs and movement within the global rankings. However, when account is taken of the three new indicators UNDP has published since 2010 to reflect "deprivation and inequalities": the Inequality-adjusted HDI, the Gender Inequality Index and the Multidimensional Poverty 
Index, progress is not always so obvious. Unfortunately, these indices are kept apart from HDI and therefore have no bearing on global HDI rankings. If the factors they measure were included in HDI together with freedoms, for instance, the order and dynamics of the rankings might be very different.

Although human development provides people with the means to achieve their aspirations, freedom is the sine qua non. As Sen rightly points out in Development and Freedom (Sen, 2000), freedom enables people within a society to better themselves in line with their aspirations and expectations and makes them better able to influence their environment.

Employment is another relevant factor in, and dimension of, development that is not considered in the HDI. Neither GDP per capita, which was formerly used to calculate the HDI, nor gross national income (GNI) per capita, which is used now, reflects the range of choices available to people to meet their needs. Employment does, however, above all because it enables people to bring to bear the capabilities they have acquired or consolidated through education for the benefit of society as a whole or themselves as individuals. A society that offers its people various sources of employment enables them to select the one that best suits their aspirations and provides them with the necessary resources to meet their needs and contribute to national development.

The ILO has stated that: “...work is the way out of poverty for poor households and... the expansion of productive and decent employment is the way economies grow and diversify" (ILO, 2012, p. 1). Further, "access to safe, productive and fairly remunerated work —as a wage employee or as an own-account worker-is a key vehicle for individuals and families to gain self-esteem, a sense of belonging to a community and a way to make a productive contribution" (ILO, 2012, p. 1).

Indeed, full and productive employment and decent work for all, including women and young people, was one of the three aims set out in 2005 with a view to achieving the first of the eight Millennium Development Goals, namely to "eradicate extreme poverty and hunger".
However, although achieving this objective is currently just as important as ever, the human development report fails to monitor it and it is not considered in the calculation of the HDI.

As a result of what have been termed "distortions of development", a society may well have a high GNI per capita due to the nature of economic activities performed within it but experience rising unemployment, making it harder for people to achieve their aspirations and perhaps even leading to a deterioration in material living conditions, a state of affairs that, moreover, would not be reflected in its HDI score.

The case of Spain is a good example of the importance of employment in human development. According to ILO data (2012), in the fourth quarter of 2011, Spain had an unemployment-to-population ratio of $22.8 \%$, which had increased by 2.5 points on the fourth quarter of 2010 . Despite this, its HDI increased from 0.863 to 0.878 .

Although development is a long-term process in which progress occurs slowly, the HDI varies constantly, as changes in any of its dimensions are reflected in HDI rankings. Can changes in employment status not also therefore influence human development? Unemployment may be cyclical, but returning to the conditions enjoyed before an economic crisis is, for example, a long and arduous process. Monitoring employment is just as important as tracking progress in education and health.

Unemployment in Spain, although caused by an economic crisis that one hopes will be short-term, has driven down people's material living standards as it has curtailed the range of options at their disposal to meet their needs. However, this impact is not evident in Spain's current HDI.

In view of this, and even though it must be recognized that there are limitations to what can be achieved in developing a composite indicator to provide a comprehensive picture of progress in human development, other factors that have hitherto been ignored by the HDI (freedom and employment) could well be added so as to broaden the range of dimensions considered. 


\section{IV}

\section{Grounds for the proposed modification of HDI}

The HDI is a composite index that incorporates other standardized indices whose thresholds are adjusted over time as the world progresses.

The HDI was designed to measure three dimensions: health, education, and GNI per capita, the first two being basic conditions to ensure a decent standard of living, and the third reflecting the availability of resources with which to acquire goods and services. So why is HDI based on just three indicators which, what is more, share the same drawback of being averages that conceal great differences within the population? According to various development reports it is because:

- Too many indicators could produce a perplexing picture of a country's development (UNDP, 1990);

- Owing to the scarcity of data on potential variables there is limited potential for using other indicators (UNDP, 1990);

- The HDI is made up of comprehensive indicators that measure data that overlaps with other indicators, such as, life expectancy at birth, which increases as progress is made in reducing the rate of mortality (UNDP, 1992); and
- The most conceptually suitable indicators are only produced for a small number of countries in relation to the amount covered by the human development reports (Klugman, Rodríguez and Choi, 2011).

More specific reasons are used to justify the selection of indicators that make up the HDI. These include those given to justify abandoning the political freedom index (PFI), namely that it: (i) was based on qualitative criteria rather than quantifiable empirical data; (ii) that it was used to analyse a complex problem on the basis of short, yes-no answers with no explanatory criteria, and (iii) it can be hard to discern why a country has been placed in a given category and not another (UNDP, 1992).

The HDI was therefore structured as shown in figure 2.

Now, however, improvements in the global monitoring of certain conditions, the availability of global statistics issued by supranational organizations and the standardization of criteria for measuring variables are proof that a sea change has occurred, and most of the reasons which justified an HDI composed of three dimensions are no longer valid. This would appear to justify the proposal to add two new dimensions: employment and freedoms.

FIGURE 2

\section{Dimensions of the Human Development Index}

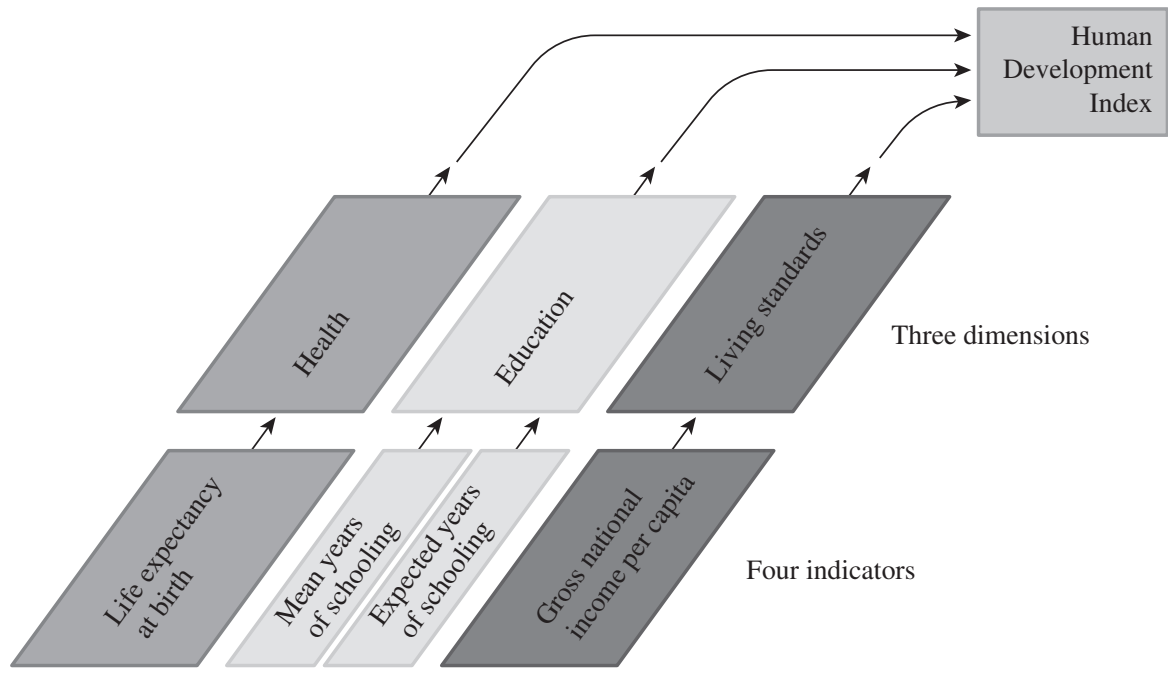

Source: own elaboration based on the United Nations Programme for Development (UNDP). 


\section{V}

\section{Employment and freedoms}

From a theoretical perspective, it would appear that new indicators can, indeed must, be incorporated into the HDI to better reflect progress in building capabilities and expanding the range of opportunities and choices within a society.

As Klugman, Rodríguez and Choi have rightly said: "The Human Development Reports have always stressed that the HDI is not and was never intended to be a definitive measure of development... the aim is to stimulate discussion and debate..." (2011, p. 7). Exploring other options would therefore entail looking into alternative ways of achieving a more detailed quantitative approach to levels of human development of a society.

This would open the way to many options for the improvement of the HDI, such as by incorporating the ecological footprint of a society to show how sustainable its patterns of consumption are. However, as per the criterion of not loading the indicator with unnecessary burdens, the intention here is to stress the fundamental dimensions of work and freedom by including them in the current HDI, as shown in figure 3.
Two indicators are proposed to measure employment, as a reflection of the choices in a society: (i) the employment-population ratio, and (ii) the proportion of non-vulnerable employment in total employment. The Democracy Index (DI) as it is called is proposed to reflect both the dimension of freedom and the opportunities on offer. These indicators are all complied using data published regularly by reliable sources such as the International Labour Organization (ILO) and the Economist Intelligence Unit (EIU).

The employment-population ratio reflects the range of options open to individuals able to work, to find a job or start a business; the proportion of non-vulnerable employment ${ }^{3}$ in total employment quantifies the supply of jobs with suitable social security entitlements, the right to unionization, adequate income and safe working conditions. It takes account not only of the quantity of employment but also of its quality, since as the ILo has

3 It includes neither own-account workers nor auxiliary family caregivers.

FIGURE 3

Proposal for a modified HDI

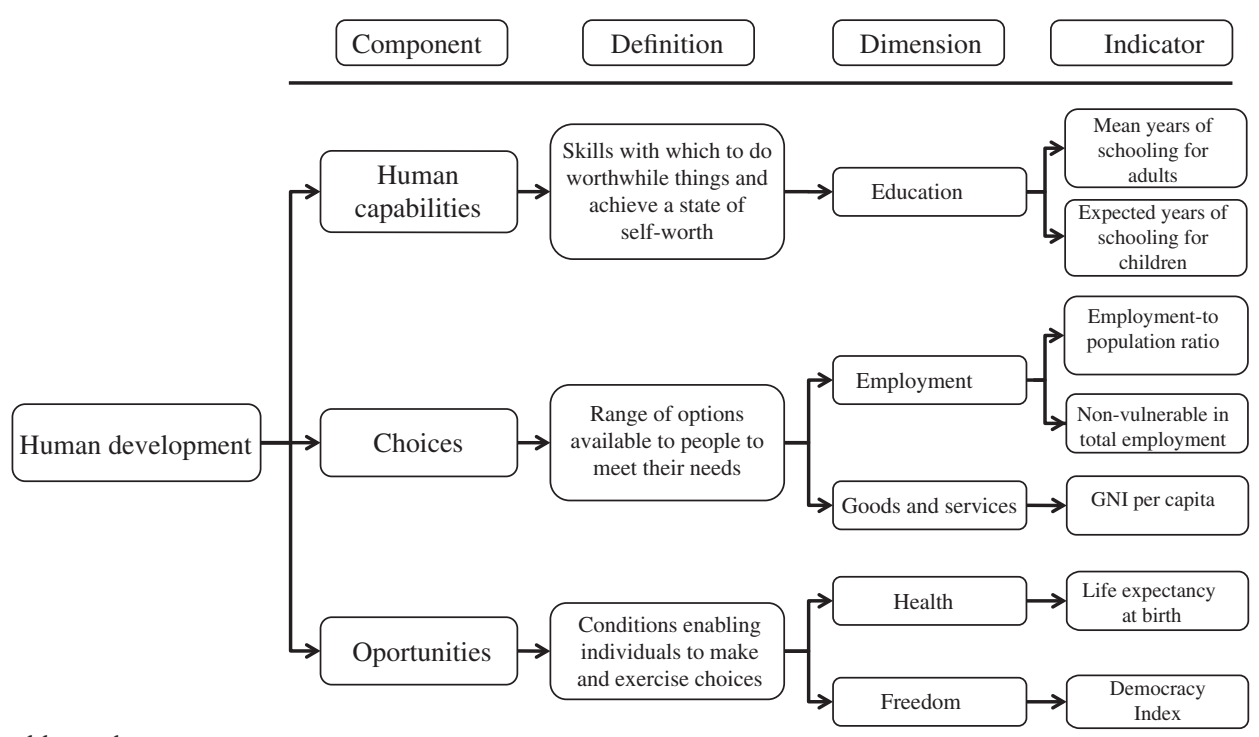

Source: prepared by author.

GNI: gross national income.

HDI: Human Development Index. 
said: "A shift to inclusive and sustainable development will not be possible if millions of people are denied the opportunity to earn their living in conditions of equity and dignity" (ILO, 2013b, p. 1).

The DI quantifies the set of political freedoms that individuals enjoy within a society and which enable them to participate in the development and administration of the rules and institutions that govern them (UNDP, 2002). Sen (2000) states that democracy encourages a society to prioritize what it aims to do and UNDP (2002) sees it not only as a value but also a means with which to achieve development.

The DI is published by the EIU and was designed to measure the state of democracy in 167 countries. Its basic premise is that free elections and civil liberties are necessary conditions for democracy, but that they are insufficient if unaccompanied by transparent and at least minimally efficient government, citizen participation and a democratic political culture (EIU, 2010).

Although studies published by the EIU suggest that there is a moderately low correlation between the DI and economic development, ${ }^{4}$ the HDI is more closely correlated with it. Estimations made for this proposal on the basis of data from 2012, gave a value of 0.7 (moderately high), and it can therefore be inferred that, while there is not a perfect correlation, human development is greater if there is democracy.

As an indicator, the DI is the simple average of responses given to a survey drawn up by experts consisting of 60 questions which places countries in one of four different, mutually exclusive categories: (i) full democracies (> 8); (ii) flawed democracies (6-7.9); (iii) hybrid regimes (4-5.9), and (iv) authoritarian regimes $(<4)$.

4 Estimated from the logarithm of GDP per capita.
The DI is made up of five categories of indicators: (i) 12 indicators on political pluralism and the electoral process; (ii) 14 indicators on how the government functions; (iii) nine indicators relating to political participation; (iv) eight indicators on the political and democratic culture, and (v) 17 indicators on civil liberties (Benavides, 2012).

The value in each category is the sum of scores given for each indicator, on a scale of 0 to 1 , where 0 is "no", 1 "yes" and 0.5 corresponds to a grey area, as clearly explained in the survey. For example: are municipal elections both free and fair? 1: free and fair; 0.5: free, but not fair; 0: neither free nor fair.

A country's score is reduced if it does not score a " 1 " in any of the following critical areas for democracy: (i) whether national elections are free and fair; (ii) the security of voters; (iii) the influence of foreign powers on government, and (iv) the capability of the civil service to implement policies. If the country scores 0 or 0.5 in the first three areas, one point is deducted from the category of "electoral process and pluralism" or "functioning of the government" category. If it scores 0 in the fourth area, one point is deducted from the "functioning of the government" category.

If the answer to certain questions is "no" ( 0 points), then the next question cannot be asked and also yields a score of 0 . For example, if the answer to the question of whether presidential and national legislative elections are free is "no" $(0)$, then the answer to the following question of whether these elections are fair must also be "no".

The DI is evidently a subjective indicator that is not without its drawbacks and can give rise to controversy. However, its scoring and aggregation system means that it can quantify the complex question of democracy in a highly meticulous manner. The advantage it has over other objective indicators, such as the number of voters, is that it attempts to bring together the factors that make up a democratic regime and quantitatively define what separates it from an authoritarian one.

\section{VI}

\section{A modified Human Development Index}

Since the HDI is made up of positive indicators, i.e. values that measure characteristics conducive to human development, and because, therefore, rises in them show improvements in these conditions, this proposal takes the same approach. Its basic premise is therefore that there is a positive correlation between employment, freedom and development, and that increases in the first two variables mean that a society has expanded the range of people's opportunities and choices. 
The proposed modification entails incorporating three subindices into the HDI: democracy, employment and non-vulnerable employment, calculated in the same manner as the education and health subindices.

To illustrate step-by-step how it is calculated, each subindex will be addressed firstly with an example, and then, using data from ILO, UNDP and EIU, the modified HDI formula will be applied to a set of countries selected by continent.

\section{Democracy subindex}

Each subindex is calculated by applying the formula used by UNDP for the HDI to data from the 2012 EIU report:

$$
\text { Subindex }=\frac{(\text { country score }- \text { lowest score })}{(\text { highest score }- \text { lowest score })}
$$

If, for example, the highest score for the DI is 9.98 points (Norway, 2010) and the lowest is 1.08 points (Democratic People's Republic of Korea, 2012) the democracy subindex for Argentina is calculated as follows using the DI for that year which is 6.84 points:

$$
\begin{aligned}
& \text { Democracy subindex }=\frac{(6.84-1.08)}{(9.98-1.08)} \\
& \text { Democracy subindex }=0.647
\end{aligned}
$$

\section{Employment and non-vulnerable employment subindices}

The HDI addresses, for example, the dimension of education using an aggregated index that is calculated on the basis of the mean years of schooling for adults and the expected years of education for children. The minimum value for both is 0 years.

As the basic premise of the minimum values in the HDI is that they relate to living conditions, the data set used to draw up minimum values for both indicators has been revised for the 2000-2010 period, which is covered by the seventh edition of Key Indicators of the Labour Market.
Between 2000 and 2010, the lowest employmentto-population ratio anywhere in the world was $34 \%$. If the rate of non-extraordinary change to this indicator is taken as 5 percentage points, a minimum global threshold of $29 \%$ can be set.

For the rate of non-vulnerable employment in total employment in respect of this period, ${ }^{5}$ a minimum threshold of $5 \%$ can be set.

Therefore, as these two minimum thresholds are different, no aggregated subindex can be estimated for employment, unlike the case with education. Individual subindices must thus be calculated for subsequent aggregation using the HDI formula.

The example below illustrates how the employment and non-vulnerable employment subindices can be calculated using the minimum values given above and the data presented in table 1 .

TABLE 1

Selected countries: employment-topopulation ratio and non-vulnerable employment ratio, 2012

\begin{tabular}{lcc}
\hline Country & $\begin{array}{c}\text { Employment-to- } \\
\text { population ratio } \\
\text { (percentage) }\end{array}$ & $\begin{array}{c}\text { Non-vulnerable } \\
\text { employment ratio }\end{array}$ \\
\hline Germany & 56.7 & 93 \\
Colombia & 60.5 & 51 \\
Sri Lanka & 52.3 & 58 \\
\hline
\end{tabular}

Source: prepared by author on the basis of data from the International Labour Organization (ILO), "Key Indicators of the Labour Market (KILM)".

Taking the maximum thresholds of $90.1 \%$ (figure reported by Qatar for 2011) for the employment-topopulation ratio and of $98 \%$ (as reported by Bahrain for 2008) for the proportion of non-vulnerable employment in total employment yields the following results:

\footnotetext{
5 ILO provides the indicator "vulnerable employment as a percentage of total employment", on the premise that it is a proportion; nonvulnerable employment is calculated by subtracting this figure from 100.

6 No rate of change over time is calculated.
} 


\begin{tabular}{|c|c|c|}
\hline 空 & $\begin{array}{l}\text { Employment subindex }=\frac{56.7-29}{90.1-29} \\
\text { Employment subindex }=0.453\end{array}$ & $\begin{array}{l}\text { Non-vulnerable employment subindex }=\frac{93-5}{98-5} \\
\text { Non-vulnerable employment subindex }=0.946\end{array}$ \\
\hline$\frac{. \frac{\pi}{0}}{\frac{\text { है }}{0}}$ & $\begin{array}{l}\text { Employment subindex }=\frac{60.5-29}{90.1-29} \\
\text { Employment subindex }=0.516\end{array}$ & $\begin{array}{l}\text { Non-vulnerable employment subindex }=\frac{51-5}{98-5} \\
\text { Non-vulnerable employment subindex }=0.495\end{array}$ \\
\hline 莺 & $\begin{array}{l}\text { Employment subindex }=\frac{52.3-29}{90.1-29} \\
\text { Employment subindex }=0.381\end{array}$ & $\begin{array}{l}\text { Non-vulnerable employment subindex }=\frac{58-5}{98-5} \\
\text { Non-vulnerable employment subindex }=0.570\end{array}$ \\
\hline
\end{tabular}

This example shows that Germany is experiencing problems in providing its people with work but is able to ensure that its citizens who are in work have adequate working conditions, are productive and have full enjoyment of their rights, unlike in Colombia where this is the case for only a small portion of the working population.

\section{Modified Human Development Index}

Using the subindices calculated above, the modified Human Development Index would be:

$\frac{\text { Modified HDI }=\sqrt[6]{\text { Health.sub } \times \text { Education.sub }}}{\times \text { Income.sub } \times \text { Democracy.sub } \times \text { Employment.sub }}$

Germany's modified HDI, using data provided by UNDP for 2010, would be:

Modified HDI $=$ $\sqrt[6]{0.955 \times 0.944 \times 0.867 \times 0.816 \times 0.453 \times 0.946}$

modified HDI $=0.806$

Table 2 provides modified HDI values calculated for the countries indicated.

A comparison of the HDI with the proposed modified HDI is shown in table 3 and figure 4.

TABLE 2

Selected countries: modified HDI, 2012

\begin{tabular}{|c|c|c|c|c|c|c|c|}
\hline Country & $\begin{array}{l}\text { Health } \\
\text { subindex }\end{array}$ & $\begin{array}{l}\text { Education } \\
\text { subindex }\end{array}$ & $\begin{array}{l}\text { Income } \\
\text { subindexs }\end{array}$ & $\begin{array}{l}\text { Democracy } \\
\text { subindex }\end{array}$ & $\begin{array}{l}\text { Employment } \\
\text { subindex }\end{array}$ & $\begin{array}{c}\text { Non- } \\
\text { vulnerable } \\
\text { employment } \\
\text { subindex }\end{array}$ & Modified HDI \\
\hline Norway & 0.966 & 0.990 & 0.913 & 0.994 & 0.563 & 0.968 & 0.883 \\
\hline Germany & 0.955 & 0.944 & 0.867 & 0.816 & 0.453 & 0.946 & 0.806 \\
\hline Argentina & 0.884 & 0.815 & 0.743 & 0.647 & 0.450 & 0.817 & 0.709 \\
\hline Brazil & 0.849 & 0.674 & 0.682 & 0.679 & 0.597 & 0.317 & 0.607 \\
\hline Colombia & 0.850 & 0.666 & 0.659 & 0.624 & 0.516 & 0.495 & 0.625 \\
\hline Spain & 0.972 & 0.871 & 0.821 & 0.780 & 0.255 & 0.892 & 0.706 \\
\hline Republic of Moldova & 0.783 & 0.714 & 0.517 & 0.589 & 0.177 & 0.710 & 0.527 \\
\hline Paraguay & 0.831 & 0.643 & 0.562 & 0.582 & 0.638 & 0.570 & 0.632 \\
\hline Peru & 0.855 & 0.713 & 0.669 & 0.606 & 0.696 & 0.591 & 0.683 \\
\hline Sri Lanka & 0.870 & 0.723 & 0.582 & 0.525 & 0.381 & 0.570 & 0.589 \\
\hline Turkey & 0.855 & 0.608 & 0.726 & 0.526 & 0.277 & 0.677 & 0.578 \\
\hline Uruguay & 0.902 & 0.764 & 0.722 & 0.797 & 0.537 & 0.785 & 0.742 \\
\hline Venezuela (Bolivarian Republic of) & 0.861 & 0.697 & 0.700 & 0.457 & 0.524 & 0.667 & 0.637 \\
\hline Russian Federation & 0.774 & 0.862 & 0.734 & 0.299 & 0.501 & 0.957 & 0.642 \\
\hline
\end{tabular}

Source: prepared by author on the basis of data from the United Nations Development Programme (UNDP) and the International Labour Organization (ILO), Informe sobre el trabajo en el mundo, 2012. Resumen de España, 2012 [online] http://www.ilo.org/wcmsp5/groups/ public/---dgreports/---dcomm/documents/briefingnote/wcms_179517.pdf. 
TABLE 3

Selected countries: HDI and modified HDI, 2012

\begin{tabular}{lccccc}
\hline Country & HDI & Ranking ${ }^{\mathrm{a}}$ & Modified HDI & Ranking ${ }^{\mathrm{b}}$ & Difference \\
\hline Norway & 0.955 & 1 & 0.883 & 1 & 0.072 \\
Germany & 0.920 & 5 & 0.806 & 7 & 0.114 \\
Argentina & 0.811 & 45 & 0.709 & 28 & 0.102 \\
Brazil & 0.730 & 85 & 0.607 & 54 & 0.123 \\
Colombia & 0.719 & 91 & 0.625 & 50 & 0.094 \\
Spain & 0.885 & 30 & 0.706 & 23 & 0.179 \\
Republic of Moldova & 0.660 & 113 & 0.527 & 74 & 0.133 \\
Paraguay & 0.669 & 111 & 0.632 & 47 & 0.037 \\
Peru & 0.741 & 74 & 0.683 & 34 & 0.058 \\
Sri Lanka & 0.715 & 92 & 0.589 & 60 & 0.126 \\
Turkey & 0.722 & 90 & 0.578 & 62 & 0.144 \\
Uruguay & 0.792 & 51 & 0.742 & 21 & 0.050 \\
Venezuela (Bolivarian Republic of) & 0.748 & 71 & 0.637 & 47 & 0.111 \\
Russian Federation & 0.778 & 55 & 0.642 & 43 & 0.136 \\
\hline
\end{tabular}

Source: prepared by author on the basis of data from the United Nations Development Programme (UNDP).

a Ranking of 187 countries.

b Ranking of 117 countries.

FIGURE 4

Selected countries: HDI and modified HDI, 2012

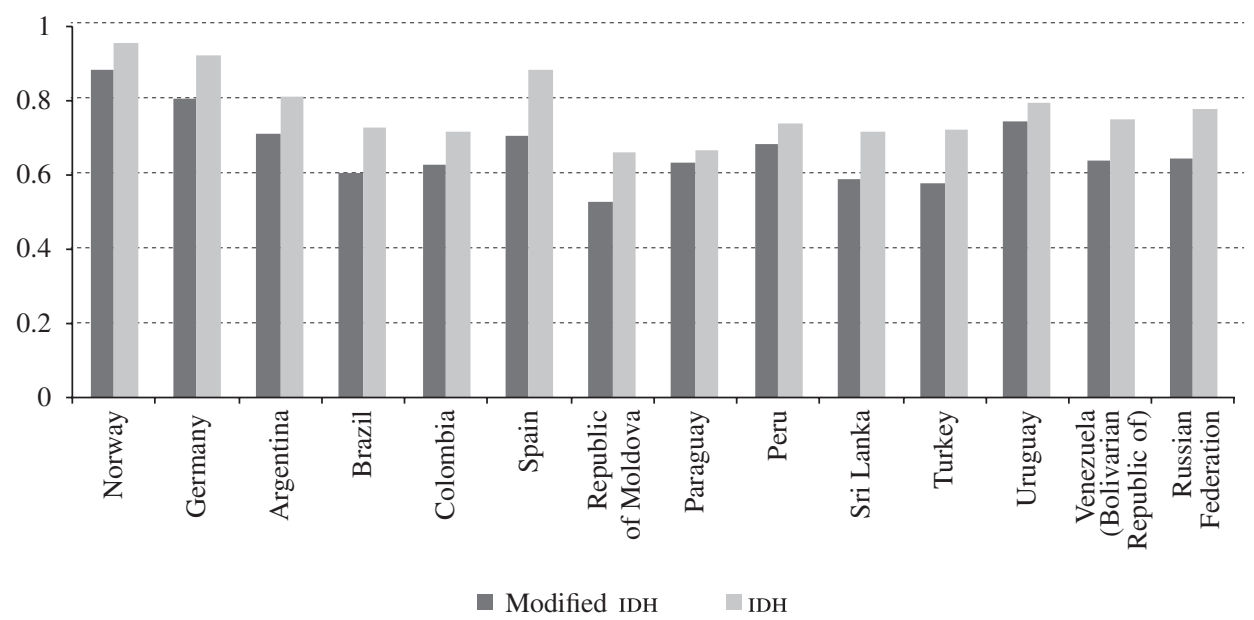

Source: prepared by author.

It should be stressed, in respect of tables 2 and 3 , as well as figure 4 that:

(i) Under the modified HDI, all countries have a lower human development score.

(ii) Under the proposed approach, the largest rise occurs in the health subindex and the greatest fall in the employment subindex.

(iii) Countries with high HDI scores, such as Norway and Germany, have a lower modified HDI owing to the influence of the employment subindex. Although these countries have the highest rates of non-vulnerable employment, they are less able to guarantee jobs for citizens of working age.

(iv) Countries with low and middling HDI scores, however, show weaknesses in their ability to provide employment and non-vulnerable employment.

(v) Spain and the Republic of Moldova are most affected by the emphasis that this approach places on employment in human development. 
(vi) Of the countries selected, the Bolivarian Republic of Venezuela and the Russian Federation, especially the latter, are the countries for which the democracy subindex has the greatest impact on their modified HDI scores.

A comparison of the countries' rankings by their HDI and modified HDI ${ }^{7}$ scores reveals that:

(i) Norway is the only country which occupies the same position in both rankings;

(ii) Countries such as Germany and Spain rank lower in the modified HDI table than in that of the HDI, chiefly as a result of the influence of employment on the former. Germany is overtaken by Denmark, Sweden and Switzerland, and Spain by countries including Argentina, Panama, Portugal, Lithuania and Slovakia in the modified HDI table;

7 See table A.1 in the statistical annex.

\section{VII}

\section{Conclusions}

The modified HDI is a proposal to fuel discussion on how to make the HDI better able to serve as a proxy for progress in human development.

It is based on two new dimensions that are essential factors in creating and expanding opportunities and choices - employment and freedoms - and makes use of three indicators that are derived from reliable sources in respect of countries that UNDP monitors regularly: (i) employment-to-population ratio; (ii) non-vulnerable employment as a share of total employment, and (iii) the Democracy Index. There is an acknowledged correlation between these indicators and human development.

The modified HDI is calculated using the same logic as the HDI, being the geometric average of its component subindices. As these subindices are provided individually, they illustrate each country's strengths and weaknesses in terms of human development.

The two dimensions added in the modified HDI help to take greater account of differences between (iii) The United Arab Emirates and the Russian Federation also move down the table, but as a result of their scores on democracy. The United Arab Emirates is overtaken by Jamaica, Trinidad and Tobago, Argentina and Costa Rica, and the Russian Federation by Peru, Malaysia and Jamaica, among others;

(iv) Botswana and Thailand are cases of note as they score substantially higher for the modified HDI than for the HDI, as a result of employment, vulnerable employment and democracy subindices that resemble those of developed countries. This places them in forty-fourth and forty-eighth place, respectively, in a ranking of 117 countries, ahead of the Bolivarian Republic of Venezuela, Turkey, Ecuador, Greece, Brazil and Bulgaria; and

(v) Chad is in last place, for two specific reasons: its low democracy subindex (0.061) and very low nonvulnerable employment subindex (0.011) gives it a modified HDI score of 0.158 . countries and provide a more accurate "snapshot" of human development. This is shown in the fact that, for instance, the modified HDI reveals that the weaknesses in countries with high overall HDI scores relate mainly to employment, while developing countries lag behind in the quality of employment.

The modified HDI also pays attention to democracy. Certain countries, including the Russian Federation and the Bolivarian Republic of Venezuela, with high HDI scores are marked down in terms of human development as a result of limits placed on political freedoms. This is also the case with Saudi Arabia and China, for example.

The modified HDI calculated for selected countries is lower than their HDI scores. This in no way diminishes the achievements they have made in human development, but rather provides a "magnifying glass" that more accurately shows where their strengths and weaknesses lie. 
STATISTICAL ANNEX

In order to show changes in countries' rankings under the modified HDI, table A.1 gives their scores for each subindex, the modified HDI and their HDI ranking.

\begin{tabular}{|c|c|c|c|c|c|c|c|c|c|}
\hline & 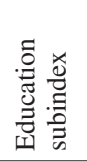 & 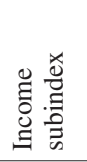 & 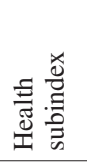 & 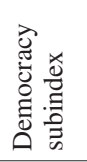 & 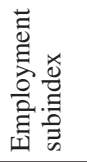 & 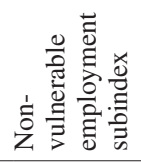 & 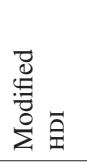 & $\mathrm{a}$ & $\mathrm{b}$ \\
\hline Norway & 0.99 & 0.913 & 0.966 & 0.994 & 0.563 & 0.968 & 0.883 & 1 & 1 \\
\hline Iceland & 0.912 & 0.838 & 0.977 & 0.963 & 0.658 & 0.935 & 0.873 & 2 & 14 \\
\hline Switzerland & 0.873 & 0.886 & 0.985 & 0.900 & 0.591 & 0.925 & 0.849 & 3 & 9 \\
\hline Sweden & 0.913 & 0.87 & 0.971 & 0.972 & 0.491 & 0.946 & 0.839 & 4 & 8 \\
\hline Denmark & 0.92 & 0.858 & 0.93 & 0.948 & 0.488 & 0.957 & 0.829 & 5 & 15 \\
\hline United States & 0.994 & 0.897 & 0.926 & 0.790 & 0.475 & 0.968 & 0.818 & 6 & 3 \\
\hline Germany & 0.944 & 0.867 & 0.955 & 0.816 & 0.453 & 0.946 & 0.806 & 7 & 5 \\
\hline Austria & 0.859 & 0.871 & 0.962 & 0.847 & 0.475 & 0.925 & 0.803 & 8 & 18 \\
\hline Japan & 0.888 & 0.854 & 1.000 & 0.787 & 0.450 & 0.968 & 0.799 & 9 & 11 \\
\hline Finland & 0.88 & 0.854 & 0.949 & 0.897 & 0.432 & 0.914 & 0.795 & 10 & 20 \\
\hline Luxembourg & 0.778 & 0.912 & 0.948 & 0.876 & 0.406 & 0.957 & 0.782 & 11 & 26 \\
\hline United Kingdom & 0.828 & 0.854 & 0.951 & 0.801 & 0.457 & 0.892 & 0.777 & 12 & 27 \\
\hline Ireland & 0.964 & 0.835 & 0.958 & 0.840 & 0.378 & 0.892 & 0.776 & 13 & 7 \\
\hline Singapore & 0.804 & 0.925 & 0.966 & 0.539 & 0.574 & 0.925 & 0.768 & 14 & 19 \\
\hline China, Hong Kong (SAR) & 0.831 & 0.904 & 0.994 & 0.600 & 0.458 & 0.957 & 0.762 & 15 & 13 \\
\hline Estonia & 0.919 & 0.762 & 0.868 & 0.734 & 0.448 & 0.968 & 0.761 & 16 & 34 \\
\hline Czech Republic & 0.916 & 0.797 & 0.912 & 0.799 & 0.419 & 0.860 & 0.759 & 17 & 28 \\
\hline Slovenia & 0.936 & 0.809 & 0.938 & 0.764 & 0.391 & 0.882 & 0.756 & 18 & 22 \\
\hline France & 0.871 & 0.843 & 0.973 & 0.764 & 0.350 & 0.946 & 0.752 & 19 & 21 \\
\hline Belgium & 0.89 & 0.858 & 0.947 & 0.783 & 0.329 & 0.914 & 0.744 & 20 & 17 \\
\hline Uruguay & 0.764 & 0.722 & 0.902 & 0.797 & 0.537 & 0.785 & 0.742 & 21 & 51 \\
\hline Malta & 0.816 & 0.791 & 0.944 & 0.809 & 0.319 & 0.925 & 0.725 & 22 & 32 \\
\hline Costa Rica & 0.713 & 0.692 & 0.937 & 0.789 & 0.481 & 0.806 & 0.722 & 23 & 62 \\
\hline Trinidad and Tobago & 0.698 & 0.796 & 0.794 & 0.664 & 0.553 & 0.849 & 0.719 & 24 & 68 \\
\hline Slovakia & 0.87 & 0.78 & 0.878 & 0.704 & 0.360 & 0.892 & 0.716 & 25 & 35 \\
\hline Lithuania & 0.873 & 0.757 & 0.829 & 0.692 & 0.375 & 0.925 & 0.713 & 26 & 41 \\
\hline Portugal & 0.741 & 0.781 & 0.942 & 0.769 & 0.375 & 0.839 & 0.713 & 27 & 43 \\
\hline Panama & 0.741 & 0.724 & 0.888 & 0.674 & 0.561 & 0.710 & 0.710 & 28 & 60 \\
\hline Argentina & 0.815 & 0.743 & 0.884 & 0.647 & 0.450 & 0.817 & 0.709 & 29 & 45 \\
\hline Latvia & 0.868 & 0.737 & 0.846 & 0.671 & 0.367 & 0.946 & 0.708 & 30 & 44 \\
\hline Spain & 0.871 & 0.821 & 0.972 & 0.780 & 0.255 & 0.892 & 0.706 & 31 & 23 \\
\hline Mauritius & 0.659 & 0.722 & 0.844 & 0.797 & 0.430 & 0.860 & 0.701 & 32 & 80 \\
\hline Poland & 0.819 & 0.765 & 0.888 & 0.679 & 0.352 & 0.828 & 0.692 & 33 & 39 \\
\hline Malaysia & 0.731 & 0.726 & 0.859 & 0.599 & 0.484 & 0.785 & 0.686 & 34 & 65 \\
\hline Peru & 0.713 & 0.669 & 0.855 & 0.606 & 0.696 & 0.591 & 0.683 & 35 & 77 \\
\hline Italy & 0.852 & 0.822 & 0.977 & 0.748 & 0.234 & 0.828 & 0.680 & 36 & 25 \\
\hline Hungary & 0.89 & 0.75 & 0.862 & 0.661 & 0.270 & 0.957 & 0.679 & 37 & 37 \\
\hline Kuwait & 0.62 & 0.925 & 0.863 & 0.303 & 0.614 & 1.000 & 0.672 & 38 & 54 \\
\hline Romania & 0.821 & 0.694 & 0.855 & 0.613 & 0.376 & 0.688 & 0.653 & 39 & 56 \\
\hline Croatia & 0.784 & 0.744 & 0.896 & 0.657 & 0.250 & 0.849 & 0.647 & 40 & 47 \\
\hline Jamaica & 0.748 & 0.621 & 0.841 & 0.709 & 0.421 & 0.624 & 0.646 & 41 & 86 \\
\hline United Arab Emirates & 0.686 & 0.894 & 0.894 & 0.169 & 0.769 & 1.011 & 0.645 & 42 & 42 \\
\hline Russian Federation & 0.862 & 0.734 & 0.774 & 0.299 & 0.501 & 0.957 & 0.642 & 43 & 55 \\
\hline Botswana & 0.683 & 0.72 & 0.521 & 0.761 & 0.561 & 0.634 & 0.641 & 44 & 119 \\
\hline Ecuador & 0.679 & 0.637 & 0.88 & 0.528 & 0.599 & 0.570 & 0.640 & 45 & 89 \\
\hline Greece & 0.856 & 0.786 & 0.947 & 0.738 & 0.205 & 0.699 & 0.638 & 46 & 29 \\
\hline Venezuela (Bolivarian Republic of) & 0.697 & 0.7 & 0.861 & 0.457 & 0.524 & 0.667 & 0.637 & 47 & 71 \\
\hline Paraguay & 0.643 & 0.562 & 0.831 & 0.582 & 0.638 & 0.570 & 0.632 & 48 & 111 \\
\hline Thailand & 0.599 & 0.642 & 0.856 & 0.615 & 0.687 & 0.452 & 0.630 & 49 & 103 \\
\hline Kazakhstan & 0.839 & 0.686 & 0.747 & 0.322 & 0.638 & 0.699 & 0.629 & 50 & 69 \\
\hline Colombia & 0.666 & 0.659 & 0.85 & 0.624 & 0.516 & 0.495 & 0.625 & 51 & 91 \\
\hline Dominican Republic & 0.625 & 0.656 & 0.846 & 0.608 & 0.444 & 0.624 & 0.623 & 52 & 96 \\
\hline El Salvador & 0.634 & 0.602 & 0.827 & 0.606 & 0.468 & 0.613 & 0.616 & 53 & 107 \\
\hline Bahrain & 0.748 & 0.776 & 0.87 & 0.174 & 0.589 & 1.000 & 0.611 & 54 & 48 \\
\hline Brazil & 0.674 & 0.682 & 0.849 & 0.679 & 0.597 & 0.317 & 0.607 & 55 & 85 \\
\hline Philippines & 0.679 & 0.535 & 0.773 & 0.587 & 0.509 & 0.591 & 0.606 & 56 & 114 \\
\hline Cape Verde & 0.445 & 0.529 & 0.856 & 0.769 & 0.535 & 0.591 & 0.605 & 57 & 132 \\
\hline
\end{tabular}




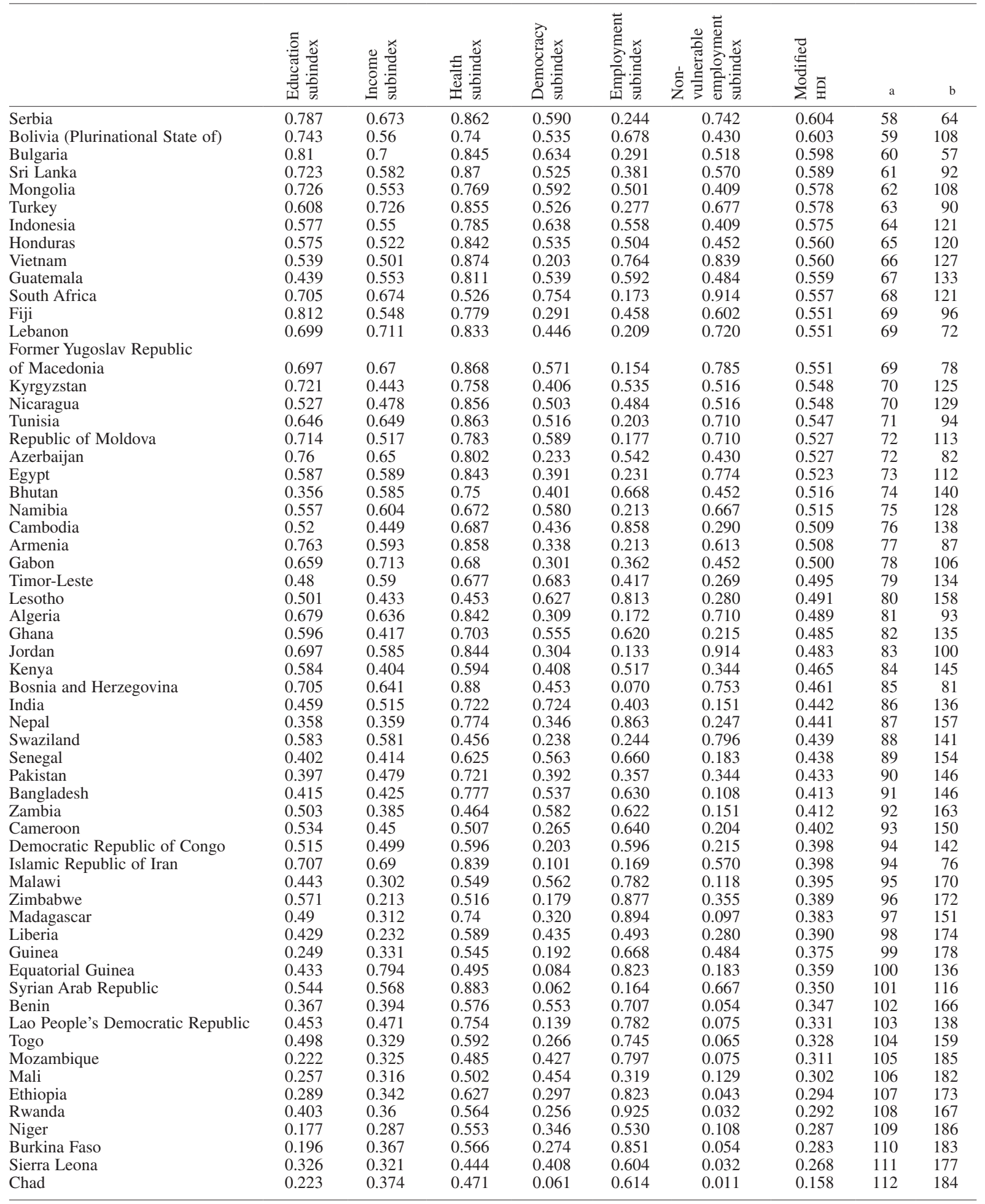

Source: prepared by author on the basis of data from the United Nations Development Programme (UNDP).

a Ranking of 187 countries.

b Ranking of 117 countries (own calculations). 


\section{Bibliography}

Benavides, J. (2012), "Índice de democracia", Boletín, No. 36, Foundation for the Development of Guatemala (FUNDESA), January [online] http://www.fundesa.org.gt/cms/content/files/ publicaciones/Boletin_de_Desarrollo_Democracy_Index.pdf.

Economist Intelligence Unit (2013), "Democracy Index 2012. Democracy at a Standstill" [online] https://portoncv.gov.cv/ dhub/porton.por_global.open_file?p_doc_id=1034.

(2010), "Democracy Index 2010. Democracy in retreat" [online] http://graphics.eiu.com/PDF/Democracy_Index_ 2010_web.pdf.

Hernández, Á. (2008), "El desarrollo humano”, El desarrollo como problema: ¿Igualdad de qué?, Ángel Hernández (comp.), Caracas, Humanistic and Scientific Development Council.

ILO (International Labour Organization) (2013b), "La importancia del empleo y los medios de vida en la agenda para el desarrollo con posterioridad a 2015" [online] http://www.ilo.org/wcmsp5/ groups/public/---dgreports/---dcomm/documents/statement/ wcms_206443.pdf.

(2012), "Informe sobre el trabajo en el mundo, 2012. Resumen de España" [online] http://www.ilo.org/wcmsp5/ groups/public/---dgreports/---dcomm/documents/briefingnote/ wcms_179517.pdf.

Johnson, L. (2010), "Aumento del empleo vulnerable y la pobreza: Entrevista con el jefe de la unidad de las tendencias mundiales del empleo de la OIT" [online] http://www.ilo.org/global/ about-the-ilo/newsroom/features/WCMS_120473/lang--es/ index.htm.

Klugman, J., F. Rodríguez and H.-J. Choi (2011), "IDH 2010: Nuevas controversias, nuevas críticas", United Nations Development Programme [online] http://hdr.undp.org/es/desarrollohumano/ hablemos-dh/2011-04/.
Recalde, Diego (1999), El desarrollo humano sostenible, Medellin, National University of Colombia [online] http://www.google. co.ve/url $? \mathrm{sa}=\mathrm{t} \& \mathrm{rct}=\mathrm{j} \& \mathrm{q}=\& \mathrm{esrc}=\mathrm{s} \&$ source $=$ web $\& \mathrm{~cd}=1 \& \mathrm{ve}$ $\mathrm{d}=0 \mathrm{CC} 4 \mathrm{QFjAA} \&$ url=http $\% 3 \mathrm{~A} \% 2 \mathrm{~F} \% 2 \mathrm{Fmedia}$.wix.com\% 2Fugd\%2F83433d_8bdaec06cf56b43b8ed8aee2d6273487. pdf\%3Fdn\%3DFor9-3-Recalde.PDF\&ei=tg_QUtHhDYbMsQSf z4HwCw\&usg=AFQjCNGX3ZX1VS2nfIcIz5vJXqXwIZ8z0Q\& sig2 = TkrHcPPTqoRlcZnhTNtPQ\&bvm=bv.59026428,d.cWc.

Sen, A. (2000), Development as Freedom, Anchor.

UNDP (United Nations Development Programme) (2013), "Indicadores y datos" [online] http://hdrstats.undp.org/es/indicadores/ 103106.html.

(2010), Human Development Report, 2010. The Real Wealth of Nations: Pathways to Human Development, New York [online] http://hdr.undp.org/en/content/human-development-report-2010.

(2002), Human Development Report, 2002. Deepening Democracy in a Fragmented World, New York [online] http:// hdr.undp.org/en/content/human-development-report-2002.

(2000), Informe sobre desarrollo humano en Venezuela, 2000. Caminos para superar la pobreza [online] http://hdr.undp.org/ sites/default/files/venezuela_2000_sp.pdf.

(1992), Human Development Report, 1992. Global Dimensions of Human Development [online] http://hdr.undp.org/es/content/ informe-sobre-desarrollo-humano-1992.

(1990), Human Development Report, 1990. Concept and Measurement of Human Development [online] http://hdr.undp. org/es/informes/mundial/idh1990/capitulos/espanol/.

Vethencourt, F. (2008), "La perspectiva de las capacidades de Amartya Sen", El desarrollo como problema: ¿Igualdad de qué?, Ángel Hernández (comp.), Caracas, Humanistic and Scientific Development Council. 